\title{
The effect of condensed tannins in Lotus corniculatus on plasma metabolism of methionine, cystine and inorganic sulphate by sheep
}

\author{
BY YUXI WANG ${ }^{1}$, G. C. WAGHORN ${ }^{2}$, T. N. BARRY ${ }^{1 *}$ AND I. D. SHELTON \\ ${ }^{1}$ Department of Animal Science, Massey University, Palmerston North, New Zealand \\ ${ }^{2}$ AgResearch Grasslands, Palmerston North, New Zealand
}

(Received 4 January 1994 - Revised 13 April 1994 - Accepted 10 May 1994)

Fresh Lotus corniculatus containing $27 \mathrm{~g}$ extractable condensed tannin (CT)/kg dry matter (DM) and $8 \mathrm{~g}$ bound CT/kg DM was fed at hourly intervals to sheep held in metabolism cages to study the effects of CT on nutrient digestion and on metabolism of methionine, cystine and inorganic sulphate in plasma. Polyethylene glycol (PEG) was continuously infused into the rumen of half the sheep to remove the effects of CT. Principal measurements in the two groups were plasma irreversible loss (IRL) rate and interconversions of methionine, cystine and inorganic sulphate using ${ }^{35} \mathrm{~S}$ labelling. $\mathrm{CT}$ in Lotus corniculatus had no effects on the apparent digestion of cellulose and minerals, slightly depressed DM, organic matter and hemicellulose digestion and markedly reduced the apparent digestion of $N(P<$ 0.01). The concentration of $\mathrm{NH}_{3}$ and molar proportions of iso-butyric acid, iso-valeric acid and $n$-valeric acid in rumen fluid were markedly increased by the PEG infusion $(P<0.01)$, whereas total volatile fatty acid concentration and molar proportions of acetic acid, propionic acid and $n$-butyric acid were not affected. PEG infusion temporarily increased rumen protozoa numbers. CT greatly increased the IRL of plasma cystine $(13.1 \nu .7 .0 \mu \mathrm{mol} / \mathrm{min} ; P<0.05)$ and reduced IRL of plasma inorganic sulphate (36.8 v. $48.1 \mu \mathrm{mol} / \mathrm{min} ; P<0.01)$ but had no effect on methionine IRL. CT increased transulphuration of methionine to cystine $(4.37 v .1 .24 \mu \mathrm{mol} / \mathrm{min} ; P<0.05)$, increased cystine entering the plasma from whole-body protein turnover plus absorption from the small intestine $(9.34 \mathrm{v} .5 .75 \mu \mathrm{mol} / \mathrm{min} ; P<0.05)$ and increased cystine flux to body synthetic reactions $(11.89 v .5 .41 \mu \mathrm{mol} / \mathrm{min} ; P<0.05)$. CT had no effect on the proportion of methionine total flux transferred to sulphate $(0.05 v .0 .06 ; P<0$.05), reduced the proportion of methionine flux transferred to body synthetic reactions $(0.68 \mathrm{v} .0 .86)$ and markedly reduced the proportion of cystine flux transferred to sulphate $(0.09 v .0 .27 ; P<0.01)$. It was concluded that $\mathrm{CT}$ in Lotus corniculatus reduced rumen protein degradation and markedly increased utilization of plasma cystine for body synthetic reactions.

Condensed tannins: Digestibility: Sulphur-containing amino acids: Inorganic sulphate: Sheep

Condensed tannins (CT) are plant secondary compounds which can react with protein and carbohydrate by hydrogen bonding in a pH-dependent manner (McLeod, 1974). Nutritional effects of CT on the ruminant animal are dependent in part on their concentration in the plant. High levels of CT (50-100 $\mathrm{g}$ extractable CT $/ \mathrm{kg}$ dry matter (DM)) have been demonstrated to depress voluntary feed intake (VFI) and reduce apparent digestibility of DM, organic matter (OM) and fibre (Donnelly \& Anthony, 1969, 1970; Reed et al. 1982; Barry \& Duncan, 1984; Barry \& Manley, 1984; Chiquette et al. 1988; Pritchard et al. 1988). In particular, rumen protein and fibre digestion are depressed. As the $\mathrm{CT}$-protein complex is stable and insoluble at $\mathrm{pH} \mathrm{3.5-7.0} \mathrm{but} \mathrm{dissociates} \mathrm{and} \mathrm{releases}$ protein at $\mathrm{pH}<3.5$ (Jones \& Mangan, 1977), low levels of CT (20-40 g extractable CT $/ \mathrm{kg}$ DM) are believed to be beneficial in ruminant diets by reducing protein degradation in the

\footnotetext{
* For reprints.
} 
rumen and increasing amino acid absorption from the small intestine, without depressing rumen fibre digestion and VFI (Barry et al. 1986; Waghorn et al. 1987a; Barry, 1989; Waghorn, 1990).

When Lotus corniculatus was fed to sheep, Waghorn et al. (1987b) found that apparent absorption of essential amino acids (EAA; excluding methionine, cystine and tryptophan) from the small intestine was increased $62 \%$ by the CT ( $22 \mathrm{~g}$ extractable $/ \mathrm{kg} \mathrm{DM})$. Apparent absorption of non-essential amino acids (NEAA) was reduced 10\%. More recently, McNabb et al. (1993) observed that in sheep fed on Lotus pedunculatus the presence of CT ( $55 \mathrm{~g}$ extractable $/ \mathrm{kg} \mathrm{DM}$ ) prevented a net loss of methionine and cystine across the rumen, and increased apparent absorption of methionine from the small intestine by $27 \%$. CT did not increase apparent absorption of cystine but it did increase both plasma irreversible loss (IRL) of cystine and the amount of cystine incorporated into body synthetic reactions, due to transulphuration of methionine to cystine. In the same study CT had no effect upon the apparent digestibility of methionine in the small intestine $(0 \cdot 78)$, but reduced the apparent digestibility of cystine in the small intestine from 0.53 to 0.42 , showing that at this concentration CT may be affecting the hydrolysis of proteins in the small intestine and reducing the apparent absorption of some amino acids.

S-containing amino acids are of particular importance for sheep because both cysteine and methionine are precursors of cystine, which is a major component of wool protein (Reis, 1979). The present experiment was designed primarily to determine the effects of CT in Lotus corniculatus on plasma IRL of S-containing amino acids, together with transulphuration of methionine to cystine and oxidation to sulphate. The experimental protocol also provided an opportunity to examine effects of CT on rumen volatile fatty acids (VFA) concentrations and rumen protozoal numbers when Lotus corniculatus was fed.

\section{MATERIALS AND METHODS}

The experiment involved fourteen castrated male Romney sheep aged 18 months which had been fitted previously with rumen cannulas $(55 \mathrm{~mm}$ i.d.). They had been grazing out of doors and were brought inside (day 1) and held indoors in metabolism cages for $34 \mathrm{~d}$. The sheep were introduced to Lotus corniculatus and allowed a 10-d adjustment period before sampling commenced.

\section{Animals}

The sheep weighed 48 (SE 1.5) $\mathrm{kg}$ at the beginning of the experiment. All were drenched with anthelmintic to control internal parasites (12 ml; Ivomec, Merck Sharp and Dohme (NZ) Ltd, Auckland, New Zealand) and treated for external parasites (10 ml; Wipeout, Coopers Animal Health, NZ Ltd, Upper Hutt, New Zealand) before the start of the experiment. The sheep had been held in metabolism cages previously. Feed intakes were recorded from day 4, and an intraruminal infusion of polyethylene glycol (PEG; molecular weight 3500) was given $(50 \mathrm{~g} / \mathrm{d}$ in $240 \mathrm{ml}$ water) to six animals commencing on day 12 and continuing until day 34 (PEG group). The PEG binds with CT, preventing the CT from binding with protein (Jones \& Mangan, 1977). The remaining eight animals did not receive an intraruminal infusion and acted as a control group.

\section{Feed}

The Lotus corniculatus was harvested daily at about 08.00 hours with a sickle-bar mower. It was vegetative throughout the trial and was fed hourly from overhead feeders. Feed was offered ad lib. for the first $7 \mathrm{~d}$ of the experiment and at about $90 \%$ of ad lib. thereafter. About $40 \%$ of the daily feed was placed on the feeders at 09.30 hours and the remainder was held at $4^{\circ}$ until 17.00 hours and then placed on the feeders. Refusals were collected each 
morning and daily DM intakes measured throughout the experimental period. Feed samples were collected at $2 \mathrm{~d}$ intervals and held separately at $-20^{\circ}$ for chemical analyses.

\section{Rumen sampling protocols}

Metal probes covered in a synthetic fibre (Estal-mono; Swiss Screens, Sydney, Australia; $88 \mu \mathrm{m}$ pore size) were suspended in the rumen, enabling fluid to be collected by gentle suction ( $20 \mathrm{ml}$ syringe). Rumen fluid was sampled between 13.00 and 15.00 hours commencing on day 11 of the experimental period (before PEG infusion) and on days 1 , $2,4,6,10,16$ and 22 after the PEG infusion started. The rumen fluid was used to determine rumen $\mathrm{NH}_{3}$ and VFA concentrations and protozoal numbers.

The rumen fluid used for the determination of $\mathrm{NH}_{3}$ concentration $(20 \mathrm{ml})$ and VFA concentration $(5 \mathrm{ml})$ was deproteinized immediately after sampling $\left(5 \mathrm{ml} 2.5 \mathrm{M}-\mathrm{H}_{2} \mathrm{SO}_{4}\right.$ saturated with $\mathrm{MgSO}_{4}$ for $\mathrm{NH}_{3}$ samples, and $1 \mathrm{ml}$ metaphosphoric acid-formic acid mixture for VFA samples). VFA protein precipitant comprised $375 \mathrm{~g}$ metaphosphoric acid and $500 \mathrm{ml}$ formic acid, made up to 2 litres. The deproteinized $\mathrm{NH}_{3}$ and VFA samples were then centrifuged at $1600 \mathrm{~g}$ and the supernatant fluid was stored at $-20^{\circ}$. The rumen fluid used to determine protozoal numbers was preserved by addition of formal saline $(9 \mathrm{~g} \mathrm{NaCl}$ and $40 \mathrm{~g} \mathrm{HCHO} / 1$ ) and stored at $4^{\circ}$.

\section{Sulphur amino acid kinetics}

Six control sheep and six PEG sheep had catheters installed in both jugular veins on day 15 of the experimental period in order to infuse $\left[{ }^{35}\right.$ S $]$ methionine (day 18 ), $\left[{ }^{35} \mathrm{~S}\right]$ cysteine (day 21 ) and ${ }^{35} \mathrm{SO}_{4}$ (day 24). Each isotope was infused continuously for $30 \mathrm{~h}$. Blood was sampled from the opposite catheter before infusion (background) and after 24, 26, 28 and $30 \mathrm{~h}$ infusion to determine the specific radioactivity (SA) of isotope in plasma. The isotopes (Amersham, Australia Pty Ltd, Auckland, New Zealand) were prepared as follows: $\left[{ }^{35}\right.$ S]methionine $(203.5 \mathrm{MBq})$ was added to 3.3 litres sterile saline containing $0.25 \mathrm{mmol} / \mathrm{l}$ inert L-methionine (BDH, Poole, Dorset) as a carrier, $\left[{ }^{35}\right.$ S]cysteine (199.8 MBq) was added to $3.2 \mathrm{l}$ sterile saline containing $0.24 \mathrm{mmol} / \mathrm{l}$ inert L-cysteine $(\mathrm{BDH})$ as a carrier and $\left[{ }^{35}\right.$ S]ammonium sulphate $(388.5 \mathrm{MBq})$ was added to 3.31 sterile saline containing $0.31 \mathrm{mmol} / 1$ inert ammonium sulphate $(\mathrm{BDH})$ as a carrier. The rates at which methionine, cysteine and inorganic sulphate were infused into each sheep were $0.4144,0.4847$ and $0.9250 \mathrm{MBq} / \mathrm{h}$ respectively.

During the methionine and cysteine infusions about $25 \mathrm{ml}$ blood per sampling time was collected into syringes with $\mathrm{Na}-\mathrm{EDTA}$ as an anticoagulant and placed on ice. The blood was centrifuged $(3000 \mathrm{~g}, 15 \mathrm{~min})$ to obtain plasma which was divided into two portions. One portion $(10 \mathrm{ml})$ was treated with $15 \mu \mathrm{l}$ 2-mercaptoethanol to reduce oxidation and centrifuged through a molecular filter (Centriprep-10 membrane filter tubes; molecular weight cut off 10000; Amican, Beverly, MA, USA) at $1900 \mathrm{~g}$ to remove large proteins. The filtrate was frozen at $-80^{\circ}$ until analysed for methionine, cysteine and cystine. A second portion $(2 \mathrm{ml}$ ) was deproteinized with $0.2 \mathrm{ml}$ trichloroacetic acid (TCA) solution $(500 \mathrm{~g} / 1)$, allowed to stand at $0^{\circ}$ for $15 \mathrm{~min}$ and was centrifuged at $3000 \mathrm{~g}$ for $20 \mathrm{~min}$. The supernatant was retained at $-80^{\circ}$ for sulphate analysis. When ${ }^{35} \mathrm{SO}_{4}$ was infused, only $10 \mathrm{ml}$ blood was collected and the plasma was deproteinized with TCA and held at $-80^{\circ}$ for analysis.

\section{Digestibility}

Following the isotope infusions, harnesses were put onto the sheep (day 26) enabling faeces collection bags to be attached for total faeces collection from day 27 to day 34 . Faeces were collected, weighed and a sample $(100 \mathrm{~g} / \mathrm{kg})$ was bulked over the $7 \mathrm{~d}$ collection period (at $-20^{\circ}$ ) for analysis. Feed DM determinations were made in triplicate $\left(95^{\circ}\right.$ for $24 \mathrm{~h}$ ) and the 
quantity of material refused was determined for each sheep. Samples of feeds and refusals were retained for analysis. Faeces DM was determined by drying at $95^{\circ}$ for $48 \mathrm{~h}$.

\section{Analytical}

Feed, feed refusal and faeces. All analyses of feeds, refusals and faeces were made with freeze-dried material. Carbohydrate fractions were determined by sequential detergent extraction (Van Soest, 1983) and total N by Kjeldahl digestion. Samples were heated at $550^{\circ}$ for $16 \mathrm{~h}$ to determine ash content in the DM. CT were determined as extractable, proteinbound and fibre-bound fractions using the modified butanol- $\mathrm{HCl}$ procedure (Terrill et al. $1992 b$ ). Total $\mathrm{S}$ in feed DM was determined after oxidation by $\mathrm{NaOBr}$ (Tabatabai \& Bremner, 1970) and feed samples for sulphate analysis were prepared by adding $1.0 \mathrm{~g}$ herbage to $50 \mathrm{ml} 0 \cdot 12 \mathrm{M}-\mathrm{HCl}$, shaking overnight and making the extract up to $250 \mathrm{ml}$. The above prepared samples were analysed using an auto-analyser (Technicon Industrial Systems, Tarrytown, MD, USA) by the modified method of Johnson \& Nishita (1952).

Rumen fluid. Rumen fluid samples were centrifuged $(950 \mathrm{~g}, 15 \mathrm{~min})$ and the supernatant was used for analysis. Rumen $\mathrm{NH}_{3}$ was determined by distilling samples which had been made weakly alkaline with sodium tetraborate $(\mathrm{pH} 9.5)$ into boric acid (10 g/1) and titrating against $0.02 \mathrm{M}-\mathrm{HCl}$ using mixed bromocresol green-methyl red indicator (Kjeltec Auto 1030 Analyzer; Kjeltec, Höganäs, Sweden). Rumen VFA were determined by capillary gas chromatography (Carlo Erba GC-5380, Italy) using a $15 \mathrm{~m} \times 0.53 \mathrm{~mm}$ i.d. FFAP $(1.0 \mu \mathrm{m}$ coat thickness column, Quadrex, Newhaven, CT, USA). The procedure used a split injection mode (approximately $2: 1$ split ratio) and a $5^{\circ} / \mathrm{min}$ temperature programme from 115 to $145^{\circ}$, with $\mathrm{H}_{2}$ as carrier gas (pressure $0.5 \mathrm{~kg} / \mathrm{cm}^{2}$ ), and a flame ionization detector. External standardization was used and the data were calculated using a Maxima 820 chromatography workstation (Waters Associates, Milford, MA, USA). Protozoa were counted in a $0.1 \mathrm{~mm}$ deep haemocytometer chamber, using light microscopy.

Plasma samples. All HPLC and radioactivity analyses for methionine, cysteine, cystine and inorganic sulphate commenced immediately after the animal work concluded. Measurement of SA from one control and one PEG sheep showed that SA of methionine, cystine and inorganic sulphate had reached plateau values after $24 \mathrm{~h}$ infusion. Therefore the plasma samples from 26,28 and $30 \mathrm{~h}$ were pooled for each sheep. The concentrations and the radioactivities of methionine, cysteine, cystine and inorganic sulphate were then determined in the bulked samples.

The concentrations of methionine, cysteine and cystine were determined by HPLC (Waters Associates), using a reverse phase Pico.Tag column for free amino acids and using the Pico.Tag analytical method for physiological samples (Cohen et al. 1989). Deproteinized plasma $(20 \mu 1)$, derivatized with phenylisothiocyanate (PITC), was injected into the column. The amino acids were detected by the fluorescence of their PITC derivatives using a Waters (USA) 490E programmable multiwavelength detector. The data were calculated using a Maxima 820 chromatography workstation (Waters Associates).

The ${ }^{35} \mathrm{~S}$ radioactivity in methionine, cysteine and cystine was determined in a $1 \mathrm{ml}$ portion of deproteinized plasma, by HPLC with an ion-exchange column, using the method described by McNabb et al. (1993). Radioactivities were counted in a liquid scintillation counter (Wallac 1409, Pharmacia, Turku, Finland).

Inorganic sulphate in deproteinized plasma was separated from organic S with Dowex 1-X8 resin (Cl-form, $18-52$ mesh size, $1.33 \mathrm{meq} / \mathrm{ml}$ binding capacity; $\mathrm{BDH}$ ). Preparation of the resin and the separation procedure were the same as described by McNabb et al. (1993), except that $3 \mathrm{M}-\mathrm{HCl}$ instead of $1 \mathrm{M}-\mathrm{HCl}$ was used to elute inorganic sulphate off the resin. The radioactivity of inorganic sulphate was deterrained by adding $1 \mathrm{ml}$ eluent to $10 \mathrm{ml}$ high-efficiency phase combining system (PCS II) and $2.0 \mathrm{ml}$ glacial acetic acid, and using a liquid scintillation counter (Wallac 1409). Inorganic sulphate concentration was 
Table 1. Chemical composition of the Lotus corniculatus ( $\mathrm{g} / \mathrm{kg}$ dry matter)

(Mean values with their standard errors for twelve samples)

\begin{tabular}{|c|c|c|c|}
\hline & & Mean & $\mathrm{SE}$ \\
\hline & Organic matter & 906 & $5 \cdot 3$ \\
\hline & Total nitrogen & $34 \cdot 8$ & 0.30 \\
\hline & NDF & 307 & $8 \cdot 3$ \\
\hline & $\mathrm{ADF}$ & 229 & 49 \\
\hline & Hemicellulose & 78 & $1 \cdot 3$ \\
\hline & Cellulose & 142 & $6 \cdot 2$ \\
\hline & Lignin & 80 & $8 \cdot 1$ \\
\hline & Total sulphur & $2 \cdot 01$ & 0.123 \\
\hline & Sulphate sulphur & 0.43 & 0.022 \\
\hline & Extractable CT & $27 \cdot 1$ & 1.69 \\
\hline & Protein-bound CT & 6.1 & 0.27 \\
\hline & Fibre-bound CT & 1.8 & 0.12 \\
\hline & Total CT & $35 \cdot 0$ & 1.78 \\
\hline
\end{tabular}

NDF, neutral-detergent fibre; ADF, acid-detergent fibre; CT, condensed tannin.

determined by the automated method of Johnson \& Nishita (1952), using an auto-analyser (Technicon Industrial Systems). All the standards used for auto-analysis were made up in $3 \mathrm{M}-\mathrm{HCl}$ which had been treated in an indentical fashion to deproteinized plasma samples.

${ }^{35}$ S-labelled methionine, cysteine and ammonium sulphate infusates were added to deproteinized plasma in order to determine the recovery of ${ }^{35} \mathrm{~S}$-labelled methionine, cysteine and sulphate in each analytical method. Radioactivity of background samples was also determined in an identical fashion.

\section{Calculation of the data and statistical analysis}

Comparison between control and PEG treatments was by analysis of variance. Means are presented with the standard error of the mean (SEM). DM and OM digestibilities were calculated on a PEG-free basis.

Both concentrations and radioactivity of cysteine and cystine were combined and expressed as cystine. The calculation of SA, IRL and transfer quotient (TQ) used methods described by $\mathrm{McNabb}$ et al. (1993). Background values were deducted in determining the SA for all metabolites. All plasma metabolite concentrations and SA values were corrected for recoveries determined for each analytical method. The results of $\mathrm{S}$ amino acid kinetics are presented as a three-pool, compartmentalized model as described by McNabb et al. (1993) and the amounts of S from inorganic sulphate transferred to methionine and cystine were assumed to be zero. Total flux was calculated as the summation of all outflows from each pool, and individual outflows were then expressed as a proportion of the total flux. Oxidation of methionine and cystine was calculated as the proportion of total flux transferred to inorganic sulphate.

\section{RESULTS}

The DM content of Lotus corniculatus was 157 (SE 9.6) $\mathrm{g} / \mathrm{kg}$, and the chemical composition of the DM showed little variation throughout the experiment (Table 1).

\section{Apparent digestibility}

During the digestibility period the DM intake of the fresh Lotus corniculatus of the control sheep (985 (SE 84.5) g DM/d) and the sheep receiving PEG (982 (SE 90.7) g DM/d) was not significantly different $(P>0.05)$. The apparent digestibilities of DM $(0.766 v .0 \cdot 786$; 

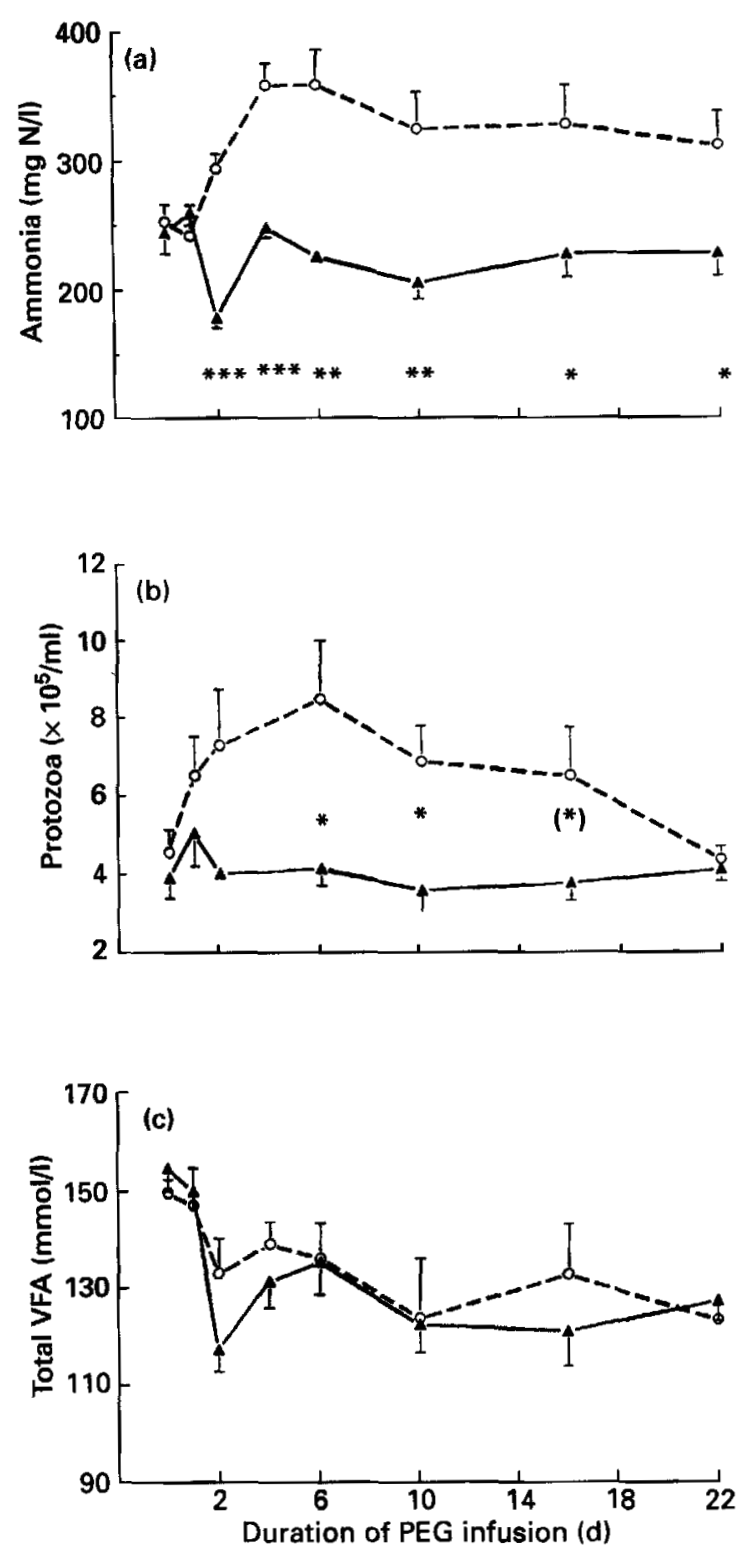

Fig. 1. The effect of intraruminal infusion of polyethylene glycol (PEG; molecular weight 3500) on (a) ammonia concentration (mg N/l), (b) protozoa numbers $\left(\times 10^{5} / \mathrm{ml}\right.$ ) and (c) total volatile fatty acid (VFA) concentration $(\mathrm{mmol} / \mathrm{l})$ in the rumen fluid of sheep fed on fresh Lotus corniculatus at hourly intervals. Values are means for six sheep per group, with their standard errors represented by vertical bars. (A- $\mathbf{A})$, Control sheep; $(0--0)$, PEGinfused sheep. Mean values were significantly different between groups: $(*) P<0.1,{ }^{*} P<0.05,{ }^{* *} P<0.01$, ${ }^{* * *} P<0.001$. For details of procedures, see pp. 924-926.

SEM 0.0079) and OM $(0.774 v .0 .797 ;$ SEM 0.0084) were lower $(P=0.084$ and 0.060 respectively) and total $N(0.721 v .0 .795$; SEM 0.0124$)$ was significantly lower $(P<0.01)$ for control than for PEG sheep. Hemicellulose apparent digestibility $(0.605$ v. 0.666; SEM 0.0256) also tended to be lower in control sheep than in PEG sheep $(P=0.118)$. However, there were no differences between control and PEG sheep in the digestibility of cellulose $(0.757$ v. 0.763 ; SEM 0.0151$)$ and minerals (0.692 v. 0.684 ; SEM 0.0097). 

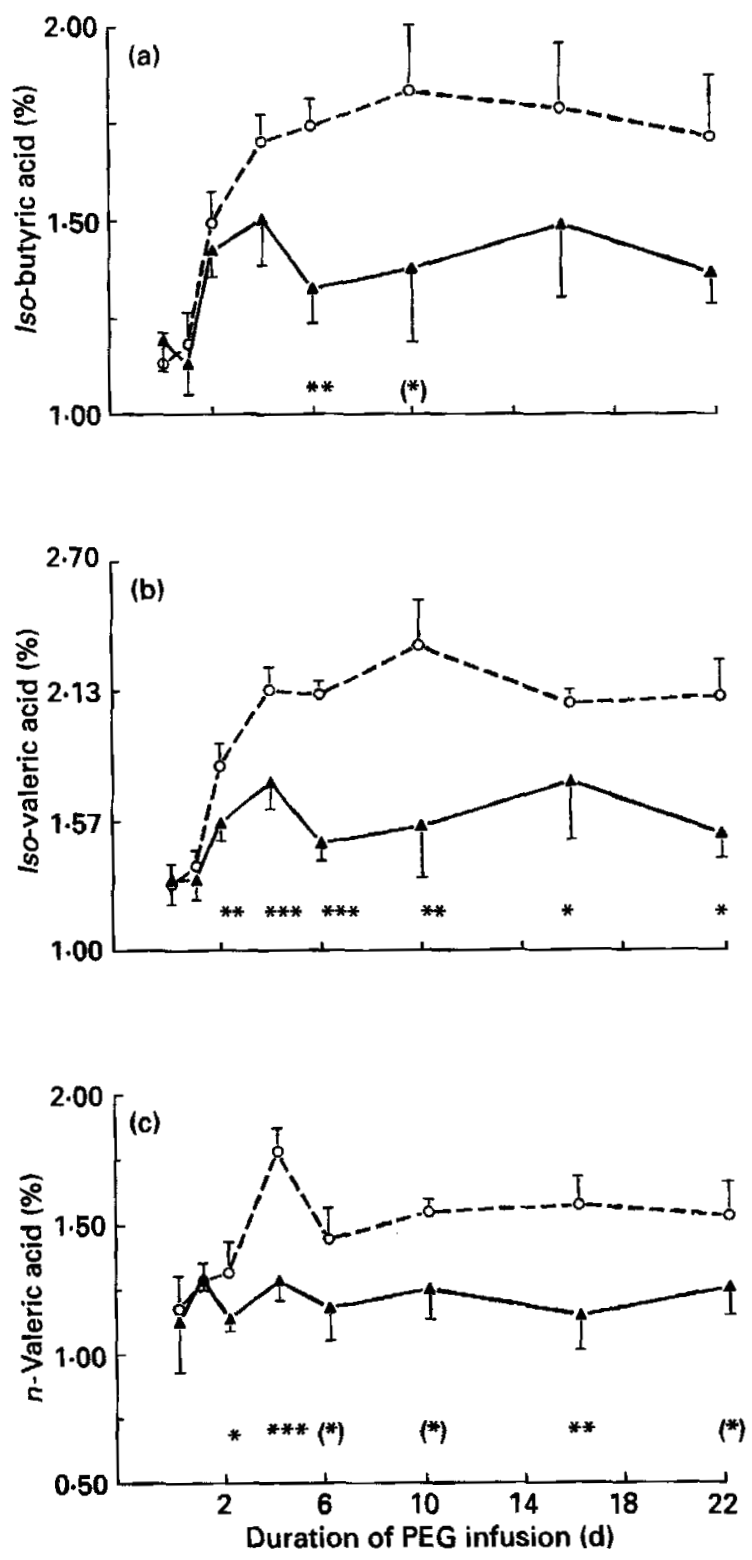

Fig. 2. The effect of intraruminal infusion of polyethylene glycol (PEG; molecular weight 3500) on the molar proportions (\%) of (a) iso-butyric acid, (b) iso-valeric acid and (c) $n$-valeric acid in the rumen fluid of sheep fed on fresh Lotus corniculatus at hourly intervals. Values are means for six sheep per group, with their standard errors represented by vertical bars. $(\boldsymbol{\Lambda}-\boldsymbol{A})$, Control sheep, (O--O), PEG-infused sheep. Mean values were significantly different between groups: $\left({ }^{*}\right) P<0.1,{ }^{*} P<0.05,{ }^{* *} P<0.01,{ }^{* * *} P<0.001$. For details of procedures see pp. 924-926.

\section{Rumen fluid}

Ammonia concentration. There were no significant differences in the concentration of $\mathrm{NH}_{3}$ in rumen fluid between control and PEG-infused sheep $(P>0.05$; Fig. 1(a)) before commencement of PEG infusion or after $1 \mathrm{~d}$ intraruminal PEG infusion. However, from 
Table 2. The concentration (umol/l), irreversible loss rate (umol/min), transfer quotients and the proportion of total fux flowing to various processes for cystine, methionine and inorganic sulphate in sheep fed on fresh Lotus corniculatus, with and without an intraruminal infusion of polyethylene glycol (PEG)†

(Mean values with their standard errors for six sheep in each group)

\begin{tabular}{|c|c|c|c|c|}
\hline & $\begin{array}{l}\text { Control } \\
\text { sheep }\end{array}$ & $\begin{array}{l}\text { PEG-infused } \\
\text { sheep }\end{array}$ & SEM & $\begin{array}{c}\text { Statistical } \\
\text { significance }\end{array}$ \\
\hline \multicolumn{5}{|l|}{ Concentration $(\mu \mathrm{mol} / \mathrm{l})$} \\
\hline Methionine & $34 \cdot 0$ & $35 \cdot 3$ & $1 \cdot 61$ & NS \\
\hline Cystine & $35 \cdot 1$ & $19 \cdot 8$ & $2 \cdot 88$ & $* *$ \\
\hline Sulphate & 1012 & 1434 & $82 \cdot 9$ & $* *$ \\
\hline \multicolumn{5}{|l|}{ Transfer quotient } \\
\hline Cystine from methionine & 0.38 & $0 \cdot 38$ & 0.036 & NS \\
\hline Sulphate from methionine & 0.01 & 0.01 & 0.001 & NS \\
\hline Sulphate from cystine & 0.03 & 0.03 & 0.003 & NS \\
\hline \multicolumn{5}{|l|}{$\begin{array}{l}\text { Irreversible loss } \\
(\mu \mathrm{mol} / \mathrm{min})\end{array}$} \\
\hline Methionine & 16.9 & 17.0 & $1 \cdot 48$ & NS \\
\hline Cystine & $13 \cdot 1$ & $7 \cdot 0$ & $1 \cdot 44$ & $*$ \\
\hline Sulphate & $36 \cdot 8$ & $48 \cdot 1$ & $2 \cdot 36$ & $* *$ \\
\hline \multicolumn{5}{|l|}{$\begin{array}{l}\text { Proportion of flux } \\
\text { transferred }\end{array}$} \\
\hline Methionine to cystine & $0 \cdot 27$ & 0.08 & 0.039 & $* *$ \\
\hline Methionine to sulphate & $0-05$ & 0.06 & 0.004 & NS \\
\hline Methionine to $\mathbf{P}+\mathbf{M}$ & 0.68 & 0.86 & $0 \cdot 040$ & $*$ \\
\hline Cystine to sulphate & $0 \cdot 09$ & 0.27 & 0.043 & $* *$ \\
\hline Cystine to $\mathbf{P}+\mathbf{M}$ & 0.91 & 0.73 & 0.043 & $* *$ \\
\hline
\end{tabular}

NS, not significant $(P>0.05) ; P+M$, production and maintenance.

$* P<0.05, * * P<0.01$.

$\dagger$ For details of procedures, see pp. 924-927.

day 2 onwards, rumen $\mathrm{NH}_{3}$ concentration was significantly lower in control sheep than in PEG-infused sheep. Rumen $\mathrm{NH}_{3}$ concentrations after 4, 6, 10, 16 and $22 \mathrm{~d}$ PEG infusion were also significantly higher $(P<0.01)$ than those before PEG infusion commencing, whereas $\mathrm{NH}_{3}$ concentration remained unchanged for control sheep during the experimental period $(P>0.05)$.

Rumen protozoa. Rumen protozoa numbers were not significantly different between control and PEG sheep before and on day 1 of the PEG infusion $(P>0.05)$, but protozoal numbers increased in PEG sheep relative to controls after 6 and $10 \mathrm{~d}(P<0.05)$ and $16 \mathrm{~d}$ $(P=0.064)$ of PEG infusion (Fig. 1(b)). By day 22 the protozoal numbers had declined in PEG sheep and were not significantly different from those of control sheep $(P>0.05)$.

Rumen VFA. Total VFA concentrations (mmol/1 rumen fluid) were similar for control (131.6 (SE 2.54) mmol/l) and PEG sheep (135.9 (SE 2.81) mmol/1) and no significant differences were detected at any sampling time (Fig. 1(c)); however, PEG infusion markedly changed molar proportions of some individual VFA (Fig. 2).

The molar proportions of acetic acid, propionic acid and $n$-butyric acid were not significantly different between control and PEG-infused sheep. Mean molar proportions of acetic acid, propionic acid and $n$-butyric acid over the entire experimental periods were 0.642 (SE 0.003), 0.220 (SE 0.004) and 0.098 (SE 0.003) for control sheep and 0.634 (SE 0.003), 0.214 (SE 0.004) and 0.104 (SE 0.002) for PEG-infused sheep. However, intraruminal infusion of PEG markedly increased the molar proportions of iso-butyric acid, iso-valeric 


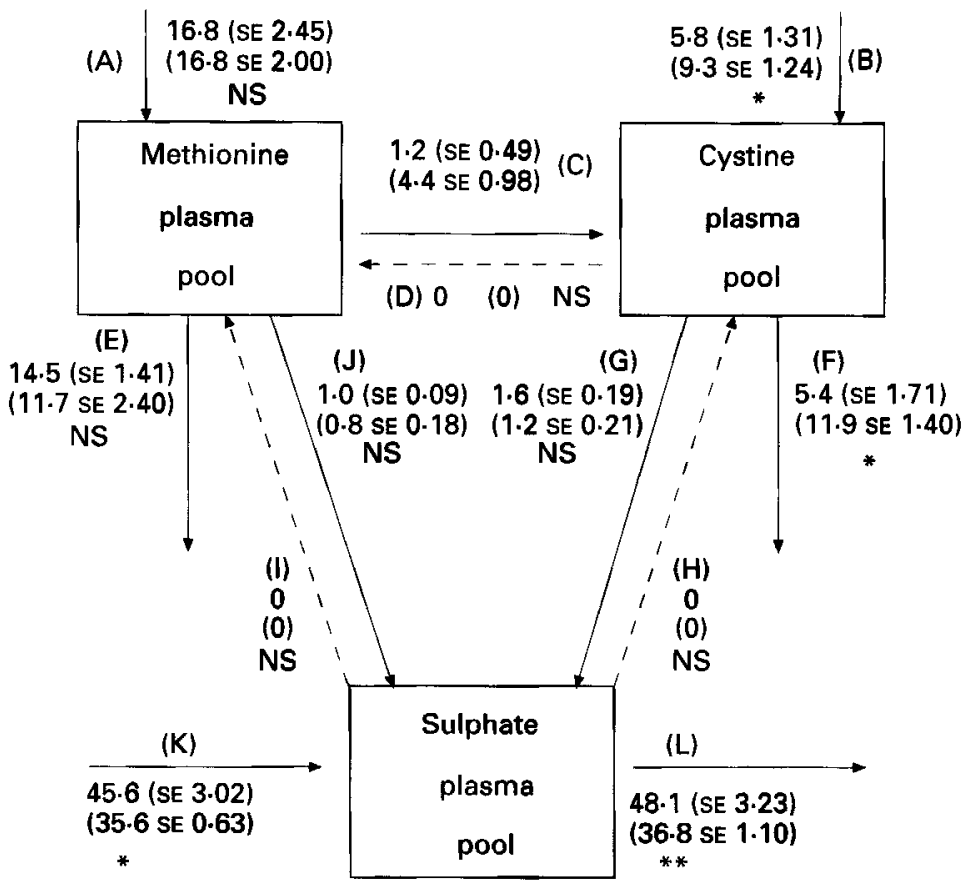

Fig. 3. A general three-pool, compartmentalized model for sulphur amino acid transactions in the posthepatic plasma of sheep fed on fresh Lotus corniculatus, with and without an intraruminal infusion of polyethylene glycol (PEG). Mean values with their standard errors are shown for six PEG-infused sheep, with the corresponding values for six control sheep given in parentheses. Mean values for PEG-infused sheep were significantly different from those for control sheep: ${ }^{*} P<0.05,{ }^{* *} P<0.01$. NS, not significant $(P>0.05)$. $\downarrow$, Rates of flow $(\mu \mathrm{mol} / \mathrm{min})$ in the model, which are often composite of several pathways of transfer. The pathways are: (A) methionine entering the plasma pool from whole-body protein turnover and absorption from the small intestine; (B) cystine entering the plasma pool from whole-body protein turnover and absorption from the small intestine; (C) transulphuration of methionine to cystine; (D) conversion of cystine to methionine, which does not occur in mammalian tissue; (E) methionine leaving the plasma and being utilized for productivity processes and maintenance; $(F)$ cystine leaving the plasma pool and being utilized for productivity processes and maintenance; (G) cystine oxidized to sulphate (and carbon dioxide); $(\mathrm{H})$ plasma sulphate reassimilated as cystine. This cannot occur directly in mammalian tissue, but sulphate re-entering the rumen via saliva may be absorbed as cystine from microbial protein; (I) plasma sulphate reassimilated as methionine. This cannot occur directly in mammalian tissue, but sulphate re-entering the rumen via saliva may be absorbed as methionine from microbial protein; (J) methionine oxidized to sulphate (and carbon dioxide); $(\mathrm{K})$ sulphate entering the plasma, chiefly from oxidation of sulphide absorbed from the rumen, but also sulphate and oxidation of sulphide absorbed from the intestine; (L) sulphate leaving the plasma chiefly in urine, but also recycled directly to the intestines and rumen via saliva.

acid and $n$-valeric acid after $2 \mathrm{~d}$ PEG infusion until the conclusion of the experiments $(P<0.05$; Fig. 2).

\section{Sulphur amino acid kinetics}

The feed intakes of the control and the PEG sheep were 989 (SE 71.4) and 983 (SE 87.6$) \mathrm{g} \mathrm{DM} / \mathrm{d}$ respectively and were not significantly different $(P>0.05)$ during the period when $\mathbf{S}$ amino acid kinetics were measured.

Methionine. The recovery of both methionine and $\left[{ }^{35} \mathrm{~S}\right] \mathrm{methionine}$ infusate added to the deproteinized plasma by HPLC was 0.97 (SE 0.02). The plasma methionine concentration and IRL rates were not significantly different between control and PEG sheep (Table 2; Fig. 3). However, the proportion of methionine total flux transferred to production and maintenance function in control sheep $(0.68)$ was lower than that in PEG sheep (0.86, 
$P<0.05$, Table 2), whilst the proportion of methionine flux transferred to cystine was much higher for control than for PEG sheep $(P<0.01)$. The proportion of methionine transferred to sulphate (i.e. oxidation) was very low $(0.05 v .0 .06 ; P>0.05)$ in control and PEG sheep respectively.

Cystine. The recovery of both cystine and $\left[{ }^{35}\right.$ S]cysteine infusate, added to the deproteinized plasma, by HPLC was 0.96 (SE 0.03). Both plasma cystine concentration $(P<0.01)$ and IRL rate $(P<0.05)$ were higher in control sheep than in PEG sheep (Table 2). Cystine flux ( $\mu \mathrm{mol} / \mathrm{min})$ into the plasma pool from both whole-body protein turnover plus absorption from small intestine and from the transulphuration of methionine were significantly higher in control sheep than in PEG sheep $(P<0.05$; Fig. 3$)$. The control sheep had a higher flux of cystine $(\mu \mathrm{mol} / \mathrm{min})$ to production and maintenance than the PEG sheep $(P<0.05)$ and a higher proportion of the cystine total flux transferred to production and maintenance than for PEG sheep $(P<0.01)$. However, the proportion of total cystine flux transferred to sulphate (i.e. oxidation) was less for control than for PEG sheep $(P<0 \cdot 01)$.

Inorganic sulphate. The recovery from the separation procedure of both $\mathrm{K}_{2} \mathrm{SO}_{4}$ and $\left[{ }^{35}\right.$ S]sulphate infusate added to the deproteinized plasma was 0.67 (SE 0.03). Control sheep had a lower plasma inorganic sulphate concentration and IRL rate than PEG sheep $(P<$ 0.01 ; Table 2). This translated into less inorganic sulphate both entering the plasma pool from the digestive system and leaving via urinary excretion or recycling to the gut in control compared with PEG sheep (Fig. 3).

\section{DISCUSSION}

The most significant result of this study was the action of $\mathrm{CT}$ in increasing the amount of cystine leaving the plasma cystine pool to be used for body synthetic reactions (11.9 v. $5.4 \mu \mathrm{mol} / \mathrm{min}$ ). This was due to increased entry flux (Fig. 3, B; $9.3 \nu .5 .8 \mu \mathrm{mol} / \mathrm{min}$ ) and increased transulphuration of methionine to cystine (Fig. 3, C; $4.4 v .1 .2 \mu \mathrm{mol} / \mathrm{min}$ ). McNabb et al. (1993) reported similar findings for the CT in Lotus pedunculatus, but cystine IRL rate determined in this experiment for control Lotus corniculatus $(13 \cdot 1 \mu \mathrm{mol} / \mathrm{min})$ was lower than that for control Lotus pedunculatus $(39.8 \mu \mathrm{mol} / \mathrm{min})$. Lee et al. (1992) also found cysteine IRL in whole blood to be lower for sheep fed on Lotus corniculatus than Lotus pedunculatus ( 11 v. $24 \mu \mathrm{mol} / \mathrm{min}$ ). This difference may be due to differences between the two Lotus species in CT reacting with plant protein and the different seasons when the two experiments were conducted.

Reactivity of CT with protein is probably a function of plant CT concentration, molecular weight and structure. Extractable and total (extractable + bound) CT were 27 and $35 \mathrm{~g} / \mathrm{kg} \mathrm{DM}$ for Lotus corniculatus (cv. Goldie) in the present study and 55 and $75 \mathrm{~g} / \mathrm{kg} \mathrm{DM}$ for Lotus pedunculatus (cv. Maku; Terrill et al. 1992 b; Douglas et al. 1993; $\mathrm{McNabb}$ et al. 1993). In addition to the effects of increased concentration, reactivity of CT with protein increases with increasing degree of CT polymerization, and hence molecular weight (Horigome et al. 1988), and with increasing ratio of the CT constituent prodelphinidin (PD) to procyanidin (PC; Jones et al. 1976). Hence the higher PD:PC ratio and molecular weight of Lotus pedunculatus CT $(70: 30 ; 2900)$ than for Lotus corniculatus CT $(27: 73 ; 2000$; Foo et al. 1982), together with the higher CT concentration, suggests that reactivity is greater for the CT in Lotus pedunculatus than in Lotus corniculatus.

Wool growth rate has been shown to be seasonal in Romney sheep in New Zealand, with highest rates in spring and summer and lowest rates in winter (Bigham et al. 1978). The experiment undertaken by McNabb et al. (1993) was carried out in spring, whereas the present study was conducted in late autumn, when wool-growth rate would be declining. 
Because of its high $\mathrm{S}$ content, which is mainly in cystine form (Reis, 1965a, $b$; Hogan, 1975), rapid wool growth will create a high demand for cystine. Therefore, compared with the results of McNabb et al. (1993), the lower flow of cystine to body synthetic reactions in the present study may also be due to lower potential wool-growth rates and hence lower cystine requirement. The increased cystine flux to body synthetic reactions due to CT could result in increased wool growth.

Results from a grazing experiment using the same sward and twice daily oral administration of PEG showed that action of CT in Lotus corniculatus increased wool growth by $12 \%(P<0.05$; Y. Wang, G. B. Douglas, G. C. Waghorn, T. N. Barry, A. G. Foot and R. W. Purchas, unpublished results). Increased wool growth due to CT has also been reported in sheep grazing sulla (Hedysarum coronarium; Terrill et al. 1992a).

The best indication of methionine and cystine oxidation in plasma is considered to be the proportion of total flux transferred to inorganic sulphate. CT markedly reduced the oxidation for cystine but not methionine, which was already low. The low cystine oxidation rate $(0.09)$ and high proportion used for production and maintenance function (0.91) in sheep fed on Lotus corniculatus with CT operating suggests that cystine availability may limit wool growth in sheep selected for high wool production.

The effects of CT are normally assessed through administration of PEG to bind and inactivate CT, and a comparison is made between control and PEG sheep (Barry et al. 1986; Waghorn et al. 1987a, b; Barry, 1989; Terrill et al. 1992 a; McNabb et al. 1993). The effects of PEG are assumed to be specific for CT and to affect only protein digestion, without affecting digestion of other nutrients, but this has not been fully investigated. The present experiments showed that PEG supplementation increased protein breakdown in the rumen, as indicated by the increased $\mathrm{NH}_{3}$ concentration. Minor VFA are produced from deamination of specific amino acids, with iso-butyric acid from valine, iso-valeric acid from leucine and $n$-valeric acid from arginine, ornithine, proline, $\sigma$-aminovaleric acid or lysine (El-Shazly, 1952; Van Soest, 1983), of which valine, leucine, arginine and lysine are EAA. Hence the reduced iso-butyric acid, iso-valeric acid and $n$-valeric acid in control compared with PEG sheep also suggests that CT reduced deamination of these EAA. However, the similarities of total VFA concentration and major VFA resulting from carbohydrate digestion (acetic acid, propionic acid and $n$-butyric acid) in control and PEG-infused sheep suggest that $35 \mathrm{~g}$ total $\mathrm{CT} / \mathrm{kg}$ in the forage DM does not affect carbohydrate digestion in the rumen.

The present results for rumen protozoa populations are opposite to the results of Terrill et al. (1992a), who found CT in sulla (29 g extractable CT and $47 \mathrm{~g}$ total CT/ $\mathrm{kg} \mathrm{DM}$ ) increased rumen protozoa counts. They explained the effect of CT in increasing protozoa numbers by the requirement of protozoa for insoluble protein and soluble carbohydrates. The rapid increase in protozoal numbers following PEG administration in the present experiment suggests inhibition of protozoa by CT. However, the response was transitory and a component may have been due to effects of PEG per se. A long-term study is needed to evaluate the effect of CT in Lotus corniculatus on rumen protozoal populations.

Tannins have been reported to inhibit digestive enzyme activities (Horigome et al. 1988; Ahmed et al. 1991; Longstaff \& McNabb, 1991 a, b; Yuste et al. 1992) and to increase endogenous $\mathrm{N}$ excretion in single-stomached animals (Price \& Butler, 1980; Cousins et al. 1981). The rapidly increasing $\mathrm{pH}$ along the small intestine may enable CT-protein complexes to be re-formed to protect protein against being hydrolysed by endogenous enzymes, or the dissociated CT may bind to the gut epithelium and affect amino acid absorption. All these could reduce the apparent digestibility of $\mathrm{N}$ in the post-ruminal digestive tract and may explain the effects of $\mathrm{CT}$ in reducing apparent $\mathrm{N}$ digestibility in the present study. Research in this area should be conducted to quantify the effects of low 
dietary $\mathrm{CT}$ levels on post-ruminal protein digestion, and especially on endogenous $\mathrm{N}$ excretion.

The results of the present study show that the lower CT concentration in Lotus corniculatus compared with Lotus pedunculatus (McNabb et al. 1993) still effectively increased the amount of cystine flowing to body synthetic reactions, but was probably close to the CT range for depressing rumen fibre digestion. Hence, Lotus species with lower contents of CT should be evaluated in order to define the optimum concentration of CT in this species for increasing the absorption of EAA, increasing the flow of S-containing amino acids to body synthetic reactions and increasing the efficiency of livestock production.

The authors wish to thank Miss R. A. Watson, Mrs M. Hendriks, Mr J. A. Anderson (Department of Animal Science, Massey University) and Mr H. B. Toes (Department of Soil Science, Massey University) for their skilled technical assistance, Mr S. Rutherfurd and $\mathrm{Mr} \mathrm{H}$. Voon of the Monogastric Research Centre (Massey University) for their guidance and advice with HPLC procedures, Associate Professor R. W. Tillman (Soil Science Department, Massey University) for his help and advice with scintillation counting, Mr G. S. Purchas for his help with harvesting Lotus plants and Miss A. C. Barry for counting protozoa.

\section{REFERENCES}

Ahmed, A. E., Smithard, R. \& Ellis, M. (1991). Activities of enzymes of the pancreas, and the lumen and mucosa of the small intestine in growing broiler cockerels fed on tannin-containing diets. British Journal of Nutrition 65, 189-197.

Barry, T. N. (1989). Condensed tannins: their role in ruminant protein and carbohydrate digestion and possible effects upon the rumen ecology. In The Role of Protozoa and Fungi in Ruminant Digestion, pp. 153-169 [J. V. Nolan, R. A. Leng and D. I. Deneyer, editors]. Armidale: Pernambul Books.

Barry, T. N. \& Duncan, S. J. (1984). The role of condensed tannins in the nutritional value of Lotus pedunculatus for sheep. 1. Voluntary intake. British Journal of Nutrition 51, 484-491.

Barry, T. N. \& Manley, T. R. (1984). The role of condensed tannins in the nutritional value of Lotus pedunculatus for sheep. 2. Quantitative digestion of carbohydrate and protein. British Journal of Nutrition 51, $493-504$.

Barry, T. N., Manley, T. R. \& Duncan, S. J. (1986). The role of condensed tannins in the nutritional value of Lotus pedunculatus. 4 . Sites of carbohydrate and protein digestion as infuenced by dietary reactive tannin concentration. British Journal of Nutrition. 55, 123-137.

Bigham, M. L., Sumner, R. M. W. \& Elliott, K. H. (1978). Seasonal wool production of Romney, Coopworth, Perendale, Cheviot, and Corriedale wethers. New Zealand Journal of Agricultural Research 21, 377-382.

Chiquette, J., Cheng, K. J., Costerton, J. W. \& Milligan, L. P. (1988). Effects of tannins on the digestibility of two isosynthetic strains of birdsfoot trefoil (Lotus corniculatus L.) using in vitro and in sacco techniques. Canadian Journal of Animal Science 68, 751-760.

Cohen, S. A., Meys, M. \& Tarvin, T. L. (1989). The Pico. Tag Method. A Manual of Advanced Techniques for Amino Acid Analysis. Milford, MA: Millipore Corporation.

Cousins, B. W., Tanksley, T. D., Knabe, D. A. \& Zebrowska, T. (1981). Nutrient digestibility and performance of pigs fed sorghums varying in tannin concentration. Journal of Animal Science 53, 1524-1537.

Donnelly, E. D. \& Anthony, W. B. (1969). Relationship of tannin, dry matter digestibility and crude protein in Sericea lespedeza. Crop Science 9, 361-362.

Donnelly, E. D. \& Anthony, W. B. (1970). Effect of genotype and tannin on dry matter digestibility in Sericea lespedeza. Crop Science 10, 200-202.

Douglas, G. B., Donkers, P., Foote, A. G. \& Barry, T. N. (1993). Determination of extractable and bound condensed tannins in forage species. In Proceedings of the XVIIth International Grasslands Conference, pp. 204-206 [M. J. Baker, J. R. Crush and L. R. Humphreys, editors]. Palmerston North, NZ: Dunmore Press.

El-Shazly, K. (1952). Degradation of protein in the rumen of the sheep. 2. The action of rumen micro-organisms on amino acids. Biochemical Journal 51, 647-653.

Foo, L. Y., Jones, W. T., Porter, L. J. \& Williams, V. M. (1982). Proanthocyanidin polymers of fodder legumes. Phytochemistry 21, 933-935.

Hogan, J. P. (1975). Symposium: protein and amino acid nutrition in the high producing cow. Quantitative aspects of nitrogen utilization in ruminants. Journal of Dairy Science 58, 1164-1177.

Horigome, T., Kumar, R. \& Okamoto, K. (1988). Effects of condensed tannins prepared from leaves of fodder plants on digestive enzymes in vitro and in the intestine of rats. British Journal of Nutrition 60, $275-285$. 
Johnson, C. M. \& Nishita, H. (1952). Microestimation of sulphur in plant materials, soils and irrigation waters. Analytical Chemistry 24, 736-742.

Jones, W. T., Broadhurst, R. B. \& Lyttleton, J. W. (1976). The condensed tannins of pasture legume species. Phytochemistry 15, 1047-1049.

Jones, W. T. \& Mangan, J. L. (1977). Complexes of the condensed tannins of Sainfoin (Onobrychis viciifolia Scop.) with fraction 1 leaf protein and with submaxillary mucoprotein, and their reversal by polyethylene glycol and $\mathrm{pH}$. Journal of the Science of Food and Agriculture 28, 126-136.

Lee, J., Harris, P. M., Sinclair, B. R. \& Treloar, B. P. (1992). The effect of condensed tannin-containing diets on whole body amino acid utilization in Romney sheep: consequences for wool growth. Proceedings of the New Zealand Saciety of Animal Production 52, 243-245.

Longstaff, M. \& McNabb, J. M. (1991 a). The inhibitory effects of hull polysaccharides and tannins of field beans (Vicia faba L, ) on the digestion of amino acids, starch and lipid and on digestive enzyme activities in young chicks. British Journal of Nutrition 65, 199-216.

Longstaff, M. A. \& McNabb, J. M. (1991 $b$ ). The effect of concentration of tannin-rich bean hulls ( Vicia faba L.) on activities of lipase $(E C 3.1 .1 .3)$ and $\alpha$-amylase $(E C$ 3.2.1.1) in digesta and pancreas and on the digestion of lipid and starch by young chicks. British Journal of Nutrition 66, 139-147.

McLeod, M. N. (1974). Plant tannins - their role in forage quality. Nutrition Abstracts and Reviews 44, 803-815.

McNabb, W. C., Waghorn, G. C., Barry, T. N. \& Shelton, I. D. (1993). The effect of condensed tannins in Lotus pedunculatus on the digestion and metabolism of methionine, cystine and inorganic sulphur in sheep. British Journal of Nutrition 70, 647-661.

Price, M. L. \& Butler, L. G. (1980). Tannins and Nutrition. Station Bulletin no. 272. Department of Biochemistry, Agricultural Experiment Station, Purdue University, West Lafayette, Indiana.

Pritchard, D. A. Stocks, D. C., O'Sullivan, B. M., Martin, P. R., Hurwood, I.S. \& O'Rourke, P. K. (1988). The effect of polyethylene glycol (PEG) on wool growth and liveweight of sheep consuming a mulga (Acacia aneura) diet. Proceedings of the Australian Society of Animal Production 17, $290-293$.

Reed, J. D., McDowell, R. E., Van Soest, P. J. \& Horvath, P. J. (1982). Condensed tannins: a factor limiting the use of Cassava forages. Journal of the Science of Food and Agriculture 33, 213-220.

Reis, P. J. (1965a). Variation in the sulphur content of wool. In Biology of the Skin and Hair Growth, pp. 365-379 [A. G. Lyne and B. F. Short, editors]. Sydney: Angus and Robertson.

Reis, P. J. (1965b). The growth and composition of wool. III. Variation in the sulphur content of wool. Australian Journal of Biological Science 18, 671-679.

Reis, P. J. (1979). Effects of amino acids on the growth and properties of wool, In Physiological and Environmental Limitations to Wool Growth, pp. 223-242 [J. L. Black and P. J. Reis, editors]. Armidale: University of New England Publishing Unit.

Tabatabai, M. A. \& Bremner, J. M. (1970). An alkaline oxidation method for determination of total sulphur in soils. Soil Science Society of America Proceedings 34, 62-65.

Terrill, T. H., Douglas, G. B., Foote, A. G., Purchas, R. W., Wilson, G. F. \& Barry, T. N. (1992a). The effect of condensed tannins upon body growth, wool growth and rumen metabolism in sheep grazing sulla (Hedysarum coronarium) and perennial pasture. Journal of Agricultural Science, Cambridge 119, 265-273.

Terrill, T. H., Rowan, A. M., Douglas, G. B. \& Barry, T. N. (1992b). Determination of extractable and bound condensed tannin concentrations in forage plants, protein concentrate meals and cereal grains. Journal of the Science of Food and Agriculture 58, 321-329.

Van Soest, P. J. (1983). Nutritional Ecology of the Ruminant. Corvallis, Oregon: O \& B Books, Inc.

Waghorn, G. C. (1990). Effect of condensed tannin on protein digestion and nutritive value of fresh herbage. Proceedings of the Australian Society of Animal Production 18, 412-415.

Waghorn, G. C., John, A., Jones, W. T. \& Shelton, I. D. (1987a). Nutritive value of Lotus corniculatus L. containing low and medium concentrations of condensed tannins for sheep. Proceedings of the New Zealand Society of Animal Production 47, 25-30.

Waghorn, G. C., Ulyatt, M. J., John, A. \& Fisher, M. T. (1987b). The effect of condensed tannins on the site of digestion of amino acids and other nutrients in sheep fed on Lotus corniculatus. British Journal of Nutrition 57 , $115-126$.

Yuste, P., Longstaff, M. \& McCorquodale, C. (1992). The effects of proanthocyanidin-rich hulls and proanthocyanidin extracts from bean (Vicia faba L.) hulls on nutrient digestibility and digestive enzyme activities in young chicks. British Journal of Nutrition 67, 57-65. 